\title{
Düşük Gerçekli Simülasyonun Kan Basıncı Bilgi Puanı ve Korotkoff Seslerini Duymaya Etkisi
}

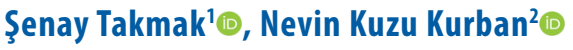

'Pamukkale Üniversitesi, Sağlık Bilimleri Enstitüsü, Hemşirelik Anabilim Dalı, Denizli, Türkiye 2Pamukkale Üniversitesi, Sağlık Bilimleri Fakültesi, Hemşirelik Esasları Anabilim Dalı, Denizli, Türkiye

Şenay Takmak, Doktora Öğrencisi Nevin Kuzu Kurban, Prof. Dr.

Illetişim:

Doktora Öğrencisi Şenay Takmak Pamukkale Üniversitesi, Sağlık Bilimleri Enstitüsü, Hemşirelik Anabilim Dalı, Denizli, Türkiye

Tel: +902582964333

E-Posta: stakmak12@hotmail.com

Gönderilme Tarihi : 04 0cak 2018

Revizyon Tarihi : : 30 Nisan 2018

Kabul Tarihi : 26 Haziran 2018
ÖZET

Amaç: Yarı deneysel uygulanan bu çalışmada düşük gerçekli simülasyonun kan basıncı bilgi puanı ve Korotkoff seslerini duymaya etkisini belirlemek amaçlanmıştır.

Bireyler ve Yöntem: Araştırmanın örneklemini bir Üniversitenin Sağlık Yüksek Okulu (deney grubu=37; kontrol grubu=35) hemşirelik birinci sınıf ögrencileri oluşturmuştur. Veriler; sosyodemografik veriler, kan basınc bilgi testi ve ölçüm sonuçları formuyla toplanmıştır. Araştırmanın uygulaması ders anlatımı, bilgi testi uygulaması (ön-son test), laboratuvar uygulaması, deney grubuna ek simülasyon eğitimi, simülatör ve sağlıkı gönüllü bireyde kan basıncı ölçüm değerlendirmesini içermektedir. Verilerin değerlendirilmesinde sayı, yüzde, ortalama, ki-kare analizi, İki eş arasındaki farkın önemlilik testi, Mann-Whitney U testi, Wilcoxon eşleştirilmiş iki örnek testi, McNemar Testi, Kruskal Wallis Varyans Analizi, iki ortalama arasındaki farkın önemlilik testi kullanılmıştır.

Bulgular: Öğrencilerinin son test bilgi ortalaması Deney grubunda 9.45 \pm 2.51 ; kontrol grubunda $10.31 \pm 2.75$ 'dır. Düşük gerçeklikli simülatör kullanılarak yapılan uygulama eğitiminin öğrencilerin bilgi testi puanlarında anlamlı bir farklılık oluşturmadığı, deney grubu öğrencilerinin simülatörde ayarlanan sesi yarıdan fazlasının 1. ve 2. ölçümlerde, kontrol grubunun 4. ölçümde duyduğu saptanmıştır. Simülatör kolunda ve sağlıklı gönüllü birey değerlendirmelerinde deney ve kontrol grubu arasında anlamlı bir farklılık bulunmamıştır.

Sonuç: Bu çalışmada düşük gerçeklikli simülatörlerin Korotkoff sesini duymada çok etkili olmadığından, yüksek gerçeklikli simülatör veya sağlıklı gönüllü bireyle yapılan beceri eğitimlerinin etkili olabileceği düşünülmektedir.

Anahtar sözcükler: Hemşirelik eğitimi, kan basıncı, bilgi, simülasyon eğitimi

\section{THE EFFECTS OF LOW FIDELITY SIMULATION ON THE BLOOD PRESSURE KNOWLEDGE SCORES AND HEARING KOROTKOFF SOUNDS}

\section{ABSTRACT}

Objectives: This semi-experimental study was conducted, to determine the effects of low fidelity simulation on blood pressure knowledge scores and hearing Korotkoff sounds.

Individuals/Materials and Methods: The sample of the study consisted of a University Health High School (experimental/ study group $=37$; control group $=35$ ) nursing, first-year students. Data that were collected: sociodemographic data, blood pressure tests and measurement results. The application of the research includes lectures, knowledge test application (pre-post test), laboratory application, additional simulation training for the experimental/study group, blood pressure measurement evaluation in a simulator and healthy volunteer. Numbers, percentages, mean, chi-square analysis, paired-samples t-test, Mann-Whitney U test, Wilcoxon signed-rank test, McNemar Test, Kruskal Wallis Variance Analysis, independent samples t-test were used in the data assessment.

Results: The experimental group post knowledge test mean was $9.45 \pm 2.51$; the control group was $10.31 \pm 2.75$. Skill training using low reality simulations did not make a significant difference between students' knowledge scores. More than half of the students in the experimental group was heard in the simulator sound at 1st and 2nd measurement, control group students was heard mainly at the 4 th measurement. There is no statistically significant difference between experimental and control groups in the assessment of simulator and healthy volunteers.

Conclusion: Since low fidelity simulators are not very effective in hearing Korotkoff sound in this study, it is thought that skill training made with high fidelity simulator or healthy volunteer individuals can be effective.

Keywords: Blood pressure, knowledge, nursing education, simulation training 
$\mathbf{H}$ emşirelik eğitimi bilişsel, duyuşsal ve psikomotor alanları içeren; sınıf, laboratuvar ve klinik eğitimle öğrenciyi gerçek hayata hazırlayan bir eğitimdir (1). Bu eğitimle öğrenciden eğitimin ilk yıllarında bazı temel klinik becerilerde yetkinleşmesi beklenir. Bu becerilerden birisi kan basıncı (KB) ölçüm becerisidir. Bu beceri, basit bir beceri olarak görülmesine rağmen hemşirelik, tıp fakültesi öğrencileri ve mezun hemşirelerde yapılan çalışmalarda becerinin bilgi ve uygulamasında eksiklik olduğu belirtilmektedir (2-7).

Kan basıncını ölçme ve değerlendirme uygulaması pek çok medikal kararı etkileyen, sağlık değerlendirmesinin en önemli göstergelerinden birisidir (8). Kan basıncı ölçümünün temel ve kolay bir beceri olarak görülmesi mezuniyet sonrası eğitimlerde yer almamasına neden olur (5) Bu durum öğrencinin kan basıncı gibi temel becerileri eğitim hayatında yetkin bir şekilde öğrenmesi zorunluluğunu ortaya koymaktadır.

Hemşirelikte her geçen gün artan öğrenci sayısı, buna karşılık laboratuvar, klinik ortam ve eğitimci sayısının yetersiz olması hemşirelik eğitiminde beceri kazanımı ve değerlendirilmesini zorlaştırmaktadır (9). Teknoloji, eğitim ve hemşirelikte yaşanan gelişmeler beceri eğitimine olan ilgiyi artırmış ve eğitimde kullanılan yöntemlerin etkinliği tartışıımaya başlanmıştır (10-11).

Hemşirelik eğitiminde simülasyon teknolojisi kullanımı ve popülaritesi giderek artmaktadır (12). Ross (2012) simülasyon kullanımını değerlendirdiği çalışmasında; beceri eğitiminde simülasyonun altın standart olma yoluna gittiğini, ancak literatürde simülasyonun yararlarını kanıtlayacak hemşirelik deneysel çalışmalarının yetersiz olduğunu ifade etmektedir (13).

Kan basıncı ölçümünde simülasyonun etkisinin değerlendirildiği çalışmalarda yeterli örneklem ile çalışamama, tasarım yetersizliği, bilgi ve becerinin birlikte ölçülememesi gibi sınırlılıklar bulunmaktadır (14-16). Eğitimdeki bu yönelmeyi destekleyecek şekilde, yeterli sayıda örneklem grubuyla, daha iyi tasarlanmış çalışmaların tüm hemşirelik becerilerini kapsayacak şekilde yapılması önerilmektedir (13-15). Bunun yanı sıra kan basıncı becerisinin yetkinliğinin ölçüldüğü çalışmalarda yüksek gerçeklikli hasta mankeni ve standart hasta simülasyonu kullanıldığı görülmektedir (15,17-18). Ancak bu simülasyon modelleri maliyet ve ulaşılabilirlik açısından sınırlılıklara sahiptir. Düşük gerçeklikteki (Low fidelity ) simülasyon modellerine ise daha kolay ulaşılmaktadır. Simülasyon modellerinin gerçekliğinden ziyade eğitimin hangi aşamasında kullanılacağına karar verilmesi gerekmektedir. Ayrıca eğitimde standardizasyonun sağlanabilmesi ve kanıta dayalı eğitim uygulanabilmesi için simülasyonun etkilerinin ortaya konduğu araştırmalar önerilmektedir $(12,19)$.

\section{Araştırmanın amacı}

Bu araştırmada, hemşirelik öğrencilerinde düşük gerçeklikli simülatör ile yapılan KB beceri eğitiminin; bilgi puanı ve Korotkoff seslerini duyma durumu üzerine etkisinin değerlendirilmesi amaçlanmıştır.

\section{Gereç ve yöntem}

Yarı deneysel olarak yapılan bu araştırma, Ege Bölgesinde bir Sağlık Yüksekokulunda 2013-2014 eğitim öğretim yılında Hemşirelik Esasları dersinde öğrenim gören öğrencilerle yapılmıştır. Yapılan güç analizine göre örnekleme en az 70 öğrencinin alınmasıyla $\% 95$ güvenle, $\% 90$ güç elde edileceği hesaplanmıştır. Öğrenciler randomize olarak deney $(n=37)$ ve kontrol $(n=35)$ gruplarına ayrılmıştır. Hemşirelik Esasları dersini ikinci kez alan öğrenciler, KB ölçümüyle ilgili ön eğitim ve deneyimi olan öğrenciler araştırma kapsamı dışında tutulmuştur.

Etik Özellikler: Araştırmanın uygulanabilmesi için ilgili Yüksekokul Müdürlüğü ve Üniversitenin Girişimsel Olmayan Tıbbi Etik Kurul'undan yazılı izin (22.01.2014, 60116787-020/4446) alınmıştır. Araştırmaya katılan tüm öğrencilerden ve sağlıklı gönüllü birey ölçümlerinde model olan öğrencilerden yazılı/sözlü onamları alınmıştır.

Veri Toplama Araçları ve Verilerin Toplanması: Araştırmada revize edilmiş ders içeriği, KB beceri rehberi, KB eğitim kolu simülatörü (LF01129U; Nasko) kullanılmıştır. Veri toplama aşamasında ise KB eğitim kolu simülatörü, çift kulaklıklı steteskop ve aneroid manometre, sosyodemografik veri toplama formu, KB bilgi testi ve ölçüm sonuçları formu kullanılmıştır.

KB eğitim kolu simülatörü: Bu simülatöre görev öğretici (task trainer) simülatör de denilmektedir ve düşük gerçeklikli simülatör grubundadır. Simülatör brakial arter ve radyal arter palpasyonu ve korotkoff sesini hoporlör bağlantısı ile dışarı verme ve korotkoff seslerini ayarlama özellikleri bulunmaktadır.

KB bilgi testi 20 sorudan oluşan çoktan seçmeli bir testtir. Her bir doğru cevap 1 puan olduğundan, testten maksimum 20 puan alınabilmektedir. Sorular çoktan seçmeli soru hazırlama tekniği, uzman görüşleri, kapsam 
geçerliğine göre hazırlanmıştır. Ön uygulama sonrası Kuder Richardson -20 (KR-20=0.68), Kuder Richardson -21 (KR-21=0.64) güvenirlik analizleri yapılmış ve kısa maddeli bir test için güvenilir kabul edilerek uygulanmıştır (20-21).

Öğrencilerin Korotkoff sesi duyma durumları KB eğitim kolu simülatöründe ayarlanan ses ve öğrencinin duyduğu ses; sağlıkı/ gönüllü bireyde çift kulaklıklı steteskop ile değerlendirici ve öğrencinin korotkoff sesi KB ölçüm sonuçları formuna kaydedilmiştir.

Araştırmanın uygulanması: Araştırmaya katılmayı kabul eden öğrenciler randomize olarak deney ve kontrol gruplarına ayrılmıştır. Dersin öğretim elemanının teorik ders anlatımı sonrası araştırma grubunun hepsine ön test kan basıncı bilgi testi uygulanmıştır. Daha sonra tüm öğrenciler beceri rehberi eşliğinde geleneksel laboratuvar uygulamasına katılmışlardır. Öğretim elemanının gözetiminde iki saatlik laboratuvar uygulamasında birbirleri üzerinde ölçüm yaparak bağımsız çalışmışlardır.

Deney grubundaki öğrencilere, müdahale olarak KB eğitim kolu simülatörü ile eğitim yapılmıştır. Simülatör ile KB eğitimi öğrencilerin ders dışında istedikleri saatlerde mesleki beceri laboratuvarında yapılmıştır. Öğrenci katılımına göre her grup 3-5er kişilik gruplar halinde eğitime alınmıştır. Eğitim; simülatörün tanıtımı, hoporlör bağlantısıyla Korotkof seslerinin dinletilmesi ve yorumlanması, simülatör üzerinde KB becerisi işlem basamaklarının gösterimi, öğrencilerin simülatör kolunda ayarlanan sesi duyma çaIışmalarından oluşmuştur. Öğrencilere simülatör üzerinde ayarlanan Korotkoff seslerini doğru duyana kadar çalışmaları sağlanmıştır. Serbest çalışmayı da kapsayan ek eğitimde süre sınırlamasına gidilmemiştir. Bu nedenle eğitim her öğrenci için ortalama 20 dakika olarak hesaplanabilmiştir.

Deney grubu müdahale eğitimi sonrası; tüm öğrencilerin KB simülatör kolu ve sağlıklı gönüllü bireyde KB ölçümleri değerlendirilmiştir. Değerlendirmede öğrencilere hem simülatör üzerinde hem de sağlıklı gönüllü bireyde en az iki, en fazla dört kere ölçüm yaptırılmıştır. Illk iki ölçümde duyamayan veya yanlış duyan öğrencilere 4. ölçüme kadar ölçüm yaptırılmıştır.

Birinci aşamada düşük gerçeklikli KB simülatör koluyla öğrencilerin ayarlanan sesleri doğru duyma durumları değerlendirilmiş ve ayarlanan değer ve öğrencinin duyduğu ses KB ölçüm sonuçları formuna kaydedilmiştir. Simülatör üzerinde Korotkoff sesi değerleri, değerlendirici tarafından rastgele ve $90 / 60 \mathrm{mmHg}-160 / 100 \mathrm{mmHg}$ aralığında ayarlanmıştır. Ölçüm sırasında öğrencinin ayarlanan değeri görmesi engellenmiştir.

Öğrenciler ikinci aşama değerlendirmede sağlıklı gönüllü bireylerde çift kulaklıklı steteskop ile ölçüm yapmışlardır. Sağlıklı gönüllü bireylerde oturur kol bir yastıkla desteklenerek ölçüm yapılmıştır. Ölçüm sonuçları değerlendirici ve öğrencinin duyduğu Korotkoff sesi KB ölçüm sonuçları formuna kaydedilmiştir

Simülatör ve sağlıklı gönüllü bireyde KB ölçümleri tamamlandıktan sonra tüm öğrencilere (ön testten üç hafta sonra) aynı KB bilgi testi uygulanmıştır.

İstatistiksel Analiz: Sürekli değişkenler ortalama \pm standart sapma ve kategorik değişkenler sayı ve yüzde olarak verilmiştir. Bağımsız grup farklılıkların karşılaştırılmasında İki Ortalama Arasındaki Farkın Önemlilik Testi; MannWhitney U testi ve Kruskal Wallis Varyans Analizi kullanılmıştır. Bağımlı grup karşılaştırmalarında, iki eş arasındaki farkın önemlilik testi; Wilcoxon eşleştirilmiş iki örnek testi kullanılmıştır. Kategorik verilerin karşılaştırılmasında ise Ki-kare analizi ve McNemar Testi kullanılmıştır. Verilerin analizinde SPSS 18.00 programı kullanılmış, $p<0.05$ değeri anlamlı olarak kabul edilmiştir.

\section{Bulgular}

Deney grubu öğrencilerinde kadınların oranı \%73; kontrol grubunda \%74.3'dür. Anadolu Lisesi mezunu olanların oranı \%59.7'dir. Her iki grubun yaş ortalamaları birbirine yakın ve ortalama $19.24 \pm 1.48$ olarak hesaplanmıştır. Deney grubu öğrencilerinin $\% 86,5^{\prime} \mathbf{i}$; kontrol grubunun ise $\% 94.3^{\prime}$ ü hemşirelik bölümüne ilk 5 tercihte yerleşmiştir. Öğrencilerin hemşirelik bölümüne giriş ÖSYM (YGS-2) puan ortalamaları 352.30 15.43 'dur. Öğrencilerin bir önceki dönem akademik ortalamaları ise $2.81 \pm 0.32$ olarak hesaplanmıştır. Deney ve kontrol grubu öğrencilerinin sosyodemografik özellikleri arasında istatistiksel olarak fark bulunmamaktadır ( $p>0.05$ ).

Deney grubu öğrencilerinin ön test KB bilgi testi bilgi puan ortalaması $9.56 \pm 2.93$, kontrol grubu öğrencilerinin $9.22 \pm 3.33$ olarak bulunmuştur. Son test ortalamaları deney grubunun $9.45 \pm 2.51$, kontrol grubunun ise $10.31 \pm 2.75$ 'dir. Deney ve kontrol grupları arasında ve grup içi ön test ve son test puanlarında anlamlı bir farklılık bulunmamıştır ( $p>0.05$ ) (Tablo 1).

Kan basınc bilgi testinin deney ve kontrol grupları içinde ön test ve son test doğru cevapları tablo 2'te 
karşılaştırılmıştır. Deney ve kontrol gruplarının ön test değerlendirmesinde istatistiksel olarak anlamlı farklılık bulunmamıştır $(p>0.05)$.

Tüm öğrencilere detaylı bir değerlendirme yapılması için ilk ölçümde ayarlanan sesi duymuş olsalar da ikinci bir ölçüm yaptırılmıştır. Deney grubu öğrencilerinin ilk iki ölçümde \%45.9'u, 2. ölçümde \%21.6'sı, 3. ölçümde \%21.6'sı,
4. ölçümde ise $\% 10.8$ i simülatörde ayarlanan sesi duymuşlardır. Kontrol grubu öğrencilerinin, ilk iki ölçümde $\% 26.5^{\prime}$ i, 2. ölçümde $\% 23.5^{\prime} i$, 3. ölçümde $\% 14.7^{\prime}$ si ve 4. ölçümde \%35.3'ü ayarlanan sesi duymuşlardır (Grafik 1).

Sağlıklı gönüllü bireyde yapılan ölçümlerde deney grubu ve kontrol grubu öğrencilerinin değerlendiriciyle aynı sesi duyma durumlarının yakın olduğu (en fazla oranda 2 .

Tablo 1. Deney ve kontrol grubu öğrencilerinin ön test ve son test KB bilgi puan ortalamalarının karşılaştıııması

\begin{tabular}{|c|c|c|c|c|c|c|}
\hline \multirow[t]{2}{*}{ Grup } & \multicolumn{2}{|c|}{$\begin{array}{c}\text { Ön Test } \\
\text { Bilgi Puanı }\end{array}$} & \multicolumn{2}{|c|}{$\begin{array}{c}\text { Son Test } \\
\text { Bilgi Puanı }\end{array}$} & \multirow{2}{*}{$\begin{array}{c}\text { Deney } \\
\text { Ön-Son Test } \\
\text { Arası Anlamlılık } \\
p 2^{\ddagger}\end{array}$} & \multirow{2}{*}{ 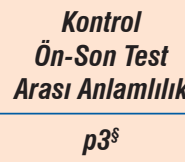 } \\
\hline & Ort. \pm S.S. & $p 1^{*}$ & Ort. \pm S.S. & $p 1^{+}$ & & \\
\hline Deney & $9.56 \pm 2.93$ & \multirow{2}{*}{0.768} & $9.45 \pm 2.51$ & \multirow{2}{*}{0.173} & \multirow{2}{*}{0.833} & \multirow{2}{*}{0.066} \\
\hline Kontrol & $9.22 \pm 3.33$ & & $10.31 \pm 2.75$ & & & \\
\hline
\end{tabular}

* Mann Whitney U Test, † iki Ortalama Arasındaki Farkı Önemlilik Testi, ‡ i ki eş arasındaki farkın önemlilik testi, § Wilcoxon eşleştirimiş iki örnek testi

Tablo 2. Kan basıncı bilgi testi ön test ve son test doğru cevaplarının deney ve kontrol grupları içinde karşılaştırıması

Bilgi Testi Madde Kökü

1. $K B^{*}$ ölçümünde doğru bir sonuç elde etmek için manşon yerleşimini bilme

2.0skültasyon tekniğinde KB ölçümü için en fazla kullanılan arteri bilme

3. Palpasyon tekniğiyle ölçülebilen KB türünü bilme

4. KB ölçümünde palpe edilen brakial arterin yerini bilme

5. KB ölçümüyle ilgili tanımlamaları bilme

6. KB değerlendirmeyle ilgili doğru bilgiyi seçme

7. Arteriyel KB'yi etkilemeyen faktörü bilme

8. KB ölçümü öncesi hastanın dinlendirilme süresini bilme

9. Yetişkin bireylerde KB normal değer aralığı

10. KB'nı değerlendirmede hipertansiyon sınıflamasını bilme

11. Hastanın KB'nin uyluktan ölçülmesi gereken durumu seçme

12. Ortostatik hipotansiyonu değerlendirebilme

13. KB yükselmesine neden olmayan durum bilme

14. KB ölçümünde manşetin maksimum şişirilme basıncına karar verme

15. Üst ektremiteden KB ölçümünde doğru pozisyonu tanımlama

16. KB ölçümünde gerçek değerden daha düşük değer elde edilmesine neden olan hatayı seçme

17. Düşük KB nedeniyle radyal nabız palpe edilemediğinde, SKB† nın belirlenme şekli

18. KB ölçümü sırasında manşonun basıncını indirir indirmez Korotkoff sesleri duyulursa ölçümün tamamlanma şekli

19. Üst koldan oskültasyonla KB ölçümünde yapılmaması gereken durumu seçme

20. KB ölçümünde sadece palpasyon yönteminin kullanııdığı durumu bilme

$\mathrm{KB}^{*}=$ Kan Basıncı SKB $\dagger=$ Sistolik Kan Basıncı
Deney Grubu $(n=37)$

Doğru cevap verenler

Kontrol Grubu ( $n=35)$

Doğru cevap verenler

\begin{tabular}{lccccc} 
Ön test & Son test & & Ön test & Son test & \\
\hline Sayı (\%) & Sayı (\%) & $x 2$ & Sayı (\%) & Sayı (\%) & $x$ 2 \\
$16(43.2)$ & $27(73.0)$ & $p=0.007$ & $19(54.3)$ & $23(65.7)$ & $p=0.424$ \\
$25(67.6)$ & $28(75.7)$ & $p=0.549$ & $21(60.0)$ & $29(82.9)$ & $p=0.039$ \\
$7(18.9)$ & $6(16.2)$ & $p=1.000$ & $3(8.6)$ & $4(11.4)$ & $p=1.000$ \\
$28(75.7)$ & $31(83.8)$ & $p=0.581$ & $29(82.9)$ & $29(82.9)$ & $p=1.000$ \\
$12(32.4)$ & $9(24.3)$ & $p=0.549$ & $11(31.4)$ & $9(25.7)$ & $p=0.727$ \\
$15(40.5)$ & $14(37.8)$ & $p=1.000$ & $10(28.6)$ & $15(42.9)$ & $p=0.227$ \\
$7(18.9)$ & $5(13.5)$ & $p=0.754$ & $8(22.9)$ & $9(25.7)$ & $p=1.000$ \\
$12(32.4)$ & $16(43.2)$ & $p=0.454$ & $16(45.7)$ & $19(54.3)$ & $p=0.581$ \\
$5(13.5)$ & $3(8.1)$ & $p=0.687$ & $3(8.6)$ & $6(17.1$ & $p=0.453$ \\
$18(48.6)$ & $28(75.7)$ & $p=0.031$ & $13(37.1)$ & $25(71.4)$ & $p=0.008$ \\
$30(81.1)$ & $29(78.4)$ & $p=1.000$ & $29(82.9)$ & $31(88.6)$ & $p=0.727$ \\
$19(51.4)$ & $11(29.7)$ & $p=0.096$ & $11(31.4)$ & $10(28.6)$ & $p=1.000$ \\
$29(78.4)$ & $20(54.1)$ & $p=0.022$ & $17(48.6)$ & $23(65.7)$ & $p=0.180$ \\
$24(64.9)$ & $26(70.3)$ & $p=0.727$ & $25(71.4)$ & $25(71.4)$ & $p=1.000$ \\
$19(51.4)$ & $13(35.1)$ & $p=0.238$ & $17(48.6)$ & $15(42.9)$ & $p=0.727$ \\
$23(62.2$ & $14(37.8)$ & $p=0.035$ & $17(48.6)$ & $21(60.0)$ & $p=0.424$ \\
$15(40.5)$ & $12(32.4)$ & $p=0.648$ & $14(40.0)$ & $15(42.9)$ & $p=1.000$ \\
$13(35.1)$ & $8(21.6)$ & $p=0.302$ & $17(48.6)$ & $8(22.9)$ & $p=0.022$ \\
& & & & & \\
$20(54.1)$ & $26(70.3)$ & $p=0.180$ & $25(71.4)$ & $23(65.7)$ & $p=0.774$ \\
$14(37.8)$ & $25(67.6)$ & $p=0.019$ & $18(51.4)$ & $24(68.6)$ & $p=0.210$ \\
& & & & &
\end{tabular}


ölçümde Deney: \%51.4; kontrol: \%48.6; p>0.05) ve anlamlı bir farklılığın olmadığı saptanmıştır (Grafik 2).

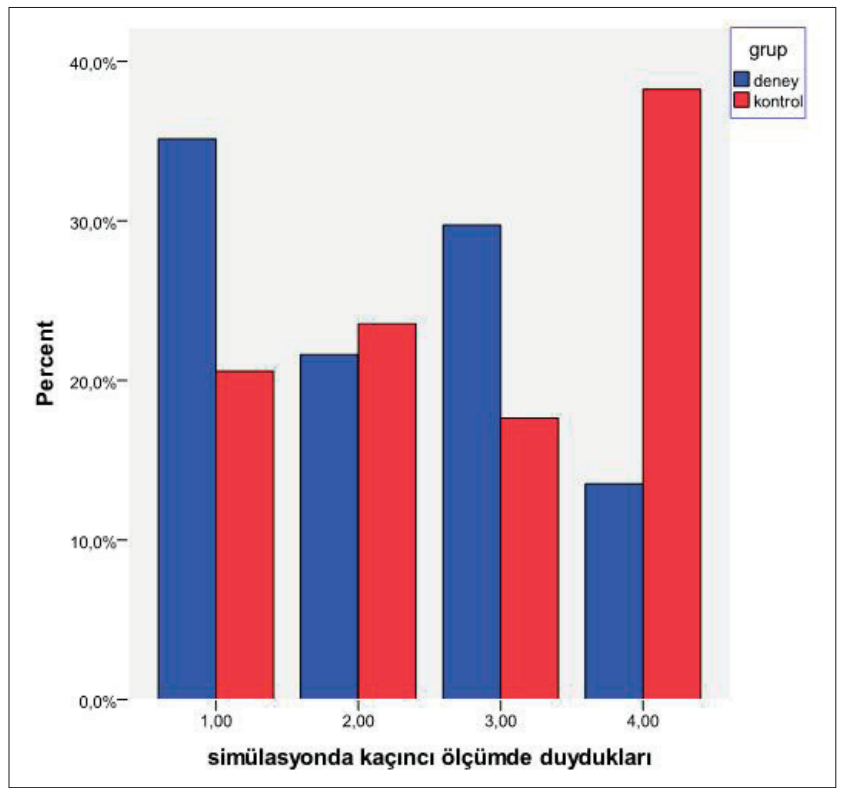

Grafik 1 Deney ve kontrol gruplarının kan basıncı simülatör kolunda ayarlanan sesi kaçıncı ölçümde duyduklarının dağılım grafiği

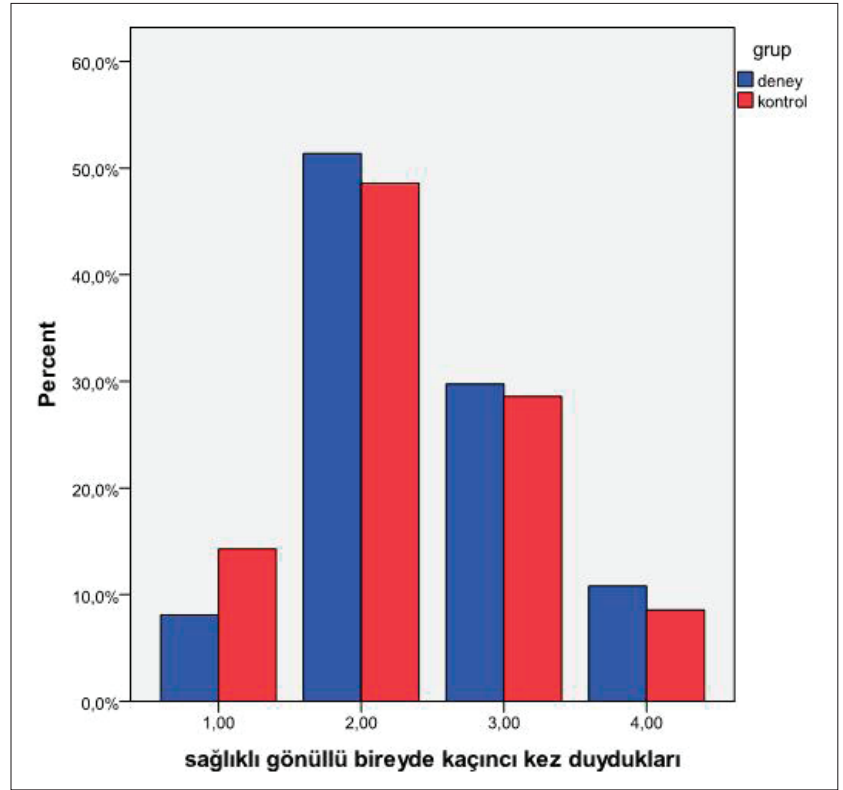

Grafik 2. Deney ve kontrol gruplarının sağlıkı gönüllü bireyde kan basıncı sesini kaçıncı ölçümde duyduklarının dağılım grafiği

\section{Tartışma}

\section{Simülasyon eğitiminin kan basıncı bilgi puanına etkisi}

Deney ve kontrol grubu öğrencilerinin sosyodemoğrafik özellikleri ve ön test bilgi puanları arasında önemli bir fark olmaması uygulanan simülasyon eğitimin bilgi ve beceriye etkisinin belirlenmesi için önemli bir durumdur. Çalışmada deney ve kontrol grubu öğrencilerinin ön test ve son testlerden aldıkları puan ortalamasının yaklaşık 10 olması (Tablo 1), öğrencilerin bilgi testi sorularının yaklaşık yarısını doğru cevapladıklarını göstermektedir.

Yapılan bir çalışmada hemşirelerin KB ölçüm bilgilerinin kısmen yetersiz olduğu bildirilmektedir (22). Tıp fakültesi 3.sınıf ve son sınıf hemşirelik öğrencilerinde yapılan diğer bir çalışmada tüm öğrencilerin yarısının doğru KB ölçüm bilgisine sahip olduklarının belirtilmesi, bu araştırmanın bulgularını desteklemektedir (5).

$\mathrm{Bu}$ araştırmada deney ve kontrol grubunun simülasyon eğitimi sonrası KB bilgi puanında anlamlı bir artış görülmemiştir. Yapılan diğer çalışmalarda interaktif videoyla (11) ve yüksek gerçeklikli simülatör ile eğitimin (17) KB bilgi puanını ve doğru karar verme becerisini artırdığı belirtilmektedir. Başka bir çalışmada, hemşirelik öğrencilerinin simülatör üzerindeki ölçümleri ve ortalama bilgi puanları arasında fark saptanmadığı, eğitimden sonra eğitim öncesine göre bilgilerinin önemli derecede artığı bildirilmiştir (23).

Araştırmada uygulanan KB bilgi testini öğrencilerin \%50 oranında cevaplamaları incelenen çalışmalardaki hemşire ve öğrenci hemşire bilgileriyle yakın olduğu düşünülmektedir $(5,7)$. Bu araştırmada deney ve kontrol gruplarında bilgi puanı kısmen düşük bulunmuştur. Bunun nedeni olarak, araştırmanın ders notunu etkilemeyeceğinin bildirilmesi, araştırma uygulamasının dönemin başında yapılması ve klinik uygulamanın başlamamış olması düşünülmektedir. Bu durum eğitim sistemimizde öğrencilerde yaygın şekilde görülen not motivasyonu ile ve sınav öncesi ders çalışmanın bir yansıması olarak görülebilir. Doğru bir ölçüm için öğrencilerin tam doğru bir bilgiye sahip olması gerektiği, bu nedenle uygulanan yöntemlerin gözden geçirilerek zenginleştirilmesi gerektiği düşünülmektedir.

$\mathrm{Bu}$ araştırmada öğrencilerin bilgi puanı ortalamalarıyla doğru ölçümü yapma durumları arasında anlamlı bir ilişki görülmemiştir ( $p>0.05)$. Orta gerçeklikli simülasyonla yapılan çalışmada deney grubunun ilk test bilgi ve yetkinlik puanı kontrol grubundan yüksek bulunurken, son testte anlamlı bir farklılık görülmemiştir (16). Seybert ve Barton (2007) yüksek gerçeklikli simülatörle yaptıkları çalışmada eğitim sonrası bilgi ve becerinin anlamlı bir şekilde arttığı belirtilmektedir (17).

\section{Grupların bilgi testine doğru cevap verme durumları}

Düşük gerçeklikli simülatör kullanılarak yapılan uygulama eğitiminde öğrencilerin bilgi testine doğru cevap verme durumlarında genel olarak anlamlı bir farklılık bulunmamıştır (Tablo 2). KB ölçümünde doğru bir sonuç elde 
etmek için manşon yerleşimini bilme maddesinde, deney grubunun ön test ve son test cevapları arasında anlamlı bir fark bulunmuştur (1). KB eğitimini 3 grupta değerlendiren çalışmada geleneksel eğitimle CD-ROM eğitimini kombine alan öğrencilerde manşon uygulaması bilgisi anlamlı olarak yüksek bulunmuştur (10). Bu çalışmanın aksine, Gazibara ve ark. (2015)'nın çalışmasında, steteskopun diaframının yerleştirilme yeri en az bilinen bilgidir (24). Bu araştırmada öğrencilerin manşon yerleşimi bilgisinin, gözlemsel çalışmaya göre iyi düzeydedir (25).

Oskültasyon tekniğinde KB ölçümü için en fazla kullanılan arter bilgisi sorulmuştur (2). Son testlerde iki grubun da doğru cevaplarının arttığı; kontrol grubunda anlamlı bir artış olduğu görülmektedir. Yapılan bir çalışmada brakial arter yeri bilgi ve uygulama düzeyinin yetersiz olduğu belirtilmektedir (22). Bu araştırmada "oskültasyon tekniğinde KB ölçümü için en fazla kullanılan arter (2) bilgisi birinci sınıf öğrencilerinin (\%76-\%83) hemşirelerden (22) yüksek oranda bilgi sahibi olduğu görülmektedir.

Deney ve kontrol grubu öğrencileri "Yetişkin bireylerde KB'nın normal değer aralığı" (9) maddesine düşük oranda doğru cevap vermelerine rağmen, "KB değerlendirmede hipertansiyon sınıflamasını bilme (10)" maddesinde son testte her iki grupta da anlamlı artış olduğu görülmüştür.

"KB ölçümünde sadece palpasyon yönteminin kullanıldığı durumu bilme (20)" maddesine öğrencilerin yaklaşık \%70'i son testte doğru cevap vermişlerdir. Gruplar arasında cevap verme durumunda anlamlı bir fark görülmezken, deney grubu içinde anlamlı bir artış oluşmuştur. Steteskop yoksa ya da Korotkoff sesleri işitilemiyorsa palpasyonla SKB. belirlenebilir. Bu yöntem maksimum şişirme basıncIna karar vermek için de kullanılabilir (8).

Son test cevap analizlerinde deney grubunun bilgi puanlarının kontrol grubundan yüksek olması beklenirken, anlamlı fark olmamasına rağmen kontrol grubunun deney grubundan daha fazla oranda sorulara doğru cevap verdiği görülmektedir. Bu durum araştırmada kullanılan düşük gerçeklikli KB kol maketiyle uygulanan simülasyon eğitiminin hemşirelik öğrencilerinde KB ölçüm ve yorumlama bilgisini artırmadığını düşündürmektedir. Genel olarak araştırmada uygulanan KB bilgi testini öğrencilerin \%50 oranında cevaplamaları incelenen çalışmalardaki hemşire ve öğrenci hemşire bilgilerine yakın olarak değerlendirilebilir. KB'de doğru bir ölçüm ve yorumlama için öğrencilerin bilgi, beceri ve tutumlarının iyi düzeyde olması gerekmektedir.
Deney ve kontrol grubu öğrencilerinin simülatör ve sağlıklı bireyde KB ölçüm sonuçlarının karşılaştırılması

Deney ve kontrol gruplarının KB ölçüm becerisi simülasyon eğitiminden sonra değerlendirilmiştir. Gruplar arasında KB ölçümünü etkileyebilecek sosyodemografik özellikleri arasında fark yoktur. Bununla birlikte sağlık meslek lisesi öğrencileri araştırmaya dâhil edilmemiştir. KB simülasyon kolu değerlendirmelerinde gruplar arasında anlamlı bir farklılık görülmemiştir. Ancak deney grubu yüzde olarak kontrol grubundan daha fazla oranda KB simülasyon kolunda ayarlanan KB sesini duymuştur.

Tanımlayıcı olarak yapılan bir çalışmada öğrencilerin $\% 10^{\prime}$ u Korotkoff seslerini duyabildiğini ve sadece 3 öğrenci dördüncü Korotkoff sesini belirleyebildiğini ifade etmişlerdir (3). Gordon ve ark. (2013) orta gerçeklikli simülatör ile eğitim müdahalesi yapmışlardır. KB değerlendirmesi gerçek hastada çift kulaklıklı steteskopla yapılmıştır. Onların çalışmalarında simülasyon eğitiminin öğrencilerde KB'yi doğru ölçmeyi iyileştirmediği, sadece öz yeterliliği arttırdığı sonucuna varmışlardır (16). Bu araştırmada benzer şekilde yapılan değerlendirmede, çift kulaklıklı steteskopla değerlendirme yapılmasının öğrencinin yetkinliğini anlamada daha objektif olma olanağı verdiği düşünülmektedir.

Yüksek gerçeklikli simülatörle yapılan bir çalışmada KB ölçüm yetkinliğinde simülasyon temelli beceri eğitiminin önemli olduğu sonucuna varılmıştır (15). Yüksek gerçeklikli simülasyonda Korotkoff seslerinin daha gerçekçi olduğu için yetkinliği artırması muhtemeldir. Bu çalışmanın yapıldığı okulda Hemşirelik Esasları dersinde geleneksel kan basıncı eğitiminde öğrenciler birbirleri üzerinde ölçüm yapmaktadırlar. Bu durum bu çalışmada gruplar arasında sağlıklı gönüllü birey ölçümlerinde farklıığın oluşmamasının bir nedeni olabileceğini düşündürmektedir. Ülkemizde yapılan yarı deneysel çalışmada standart hasta ile yapılan KB eğitiminin anlamlı şekilde etkili olması bu düşünceyi desteklemektedir (18).

\section{Sonuç ve öneriler}

Bu araştırma kapsamında düşük gerçeklikli KB simülatör uygulamasının genel KB bilgi puanında ve simülatör kolunda ve sağlıklı gönüllü bireyde KB ölçüm sonuçları arasında anlamlı fark bulunmamıştır. Korotkoff sesini doğru yorumlamak için yüksek gerçeklikli simülasyon mankeni ya da sağlıklı gönüllü bireylerle beceri eğitimi yapılmasının etkili olacağı düşünülmektedir. 
Bu araştırmada araştırmacı sayısının kısıtlı olması nedeniyle randomizasyon ve değerlendirmede körleme yapılamamıştır. Araştırma kapsamında KB ölçümünde Korotkoff sesi duyma durumu değerlendirilmiş, ölçüm basamaklarına uyma durumu gözlenmemiştir.

Birinci sınıf öğrencilerinin KB eğitimi laboratuvar ve klinik uygulamalarının ilk haftalarında çift kulaklıklı steteskopla

\section{Kaynaklar}

1. Oermann MH, editor. Teaching in Nursing and Role of the Educator. New York: Springer Puplising Company; 2015. pp.36-40.

2. Torrance C, Sergisson E. An observational study of student nurses' measurement of arteriyal blood pressure by spygmomanometry and auscultation. Nurs Educ Today 1996;16:282-86. [CrossRef]

3. Torrance C, Serginson E. Student nurses' knowledge in relation to blood pressure measurement by sphygmomanometry and auscultation sphygmomanometry and auscultation. Nurse Educ Today 1996;16:397-402. [CrossRef]

4. Armstrong RS. Nurses' knowledge of error in blood pressure measurement technique. Int J Nurs Pract 2002;8:118-26. [CrossRef]

5. Gonzalez-Lopez JJ, Ramirez JGA, Garcia RT, Esteban SA, del Barrio JA, Rodríguez-Artalejo F. F. Knowledge of correct blood pressure measurement procedures among medical and nursing students. Rev Esp Cardiol (Engl Ed) 2009;62:568-71. [CrossRef]

6. Baillie L, Curzio J. A survey of first year student nurses' experiences of learning blood pressure measurement. Nurs Educ Pract 2009;9:6171. [CrossRef]

7. Uysal H, Enç N. Hemşirelerin indirekt arteriyel kan basıncı ölçümüne ilişkin teorik ve uygulamaya yönelik bilgilerinin değerlendirilmesi. Ege Üniv Hem YO Derg 2005;21:47-61. Erişim: https://dergipark.org. tr/download/issue-file/8783

8. Berman A, Snyder S, editors. Kozier \& Erb's Fundamentals of Nursing, 9th ed. New Jersey: Pearson; 2012. pp.560-7.

9. Corbally MA. Considering video production? Lessons learned from the production of a blood pressure measurement video. Nurse Educ Pract 2005;5:375-9. [CrossRef]

10. Bauer MD, Huynh MV. Nursing students'blood pressure measurement following CD-ROM and conventional classroom instruction: a pilot study. Int J Med Inform 1998;50:103-9. [CrossRef]

11. Beeson SA, Kring DL. The effects of two teaching methods on nursing students' factual knowledge and performance of psychomotor skills. J Nurs Educ 1999;38:357-60.

12. Jeffries PR, editor. Clinical Simulations in Nursing Education. Advanced Concepts, Trends and Opportuties. Philadelphia: Wolters Kluwer Health; 2014. pp.22-44.

13. Ross JG. Simulation and psychomotor skill acquisition: a review of the literature. Clin Simul Nurs 2012;8:e429-35. [CrossRef]

14. Ballard G, Piper S, Stokes P. Effect of simulated learning on blood pressure measurement skills. Nurs Stand 2012;27:43-7. [CrossRef]

15. Karadag A, Caliskan N, Korkut H, Baykara ZG, Ozturk D. The effect of simulation training on the learning of some psychomotor skills by first year nursing students: the case of Turkey. Procedia - Soc Behav Sci 2012;47:781-85. [CrossRef] uygulama yapılması; simülasyon yönteminin etkisinin belirlenebilmesi için daha fazla değerlendiriciyle, uygulama basamaklarının tamamının gözlendiği, aynı öğrencinin iki farklı gözlemci tarafından değerlendirildiği çalışmaların yapılması önerilmektedir. Bununla birlikte simülasyon maketlerinin senaryo temelli uygulamalarla becerinin bütüncül olarak aktarılmasının daha yararlı olabileceği düşünülmektedir.

16. Gordon CJ, Frotjold A, Fethney J, Green J, Hardy J, Maw M, Buckley $T$. The effectiveness of simulation-based blood pressure training in preregistration nursing students. Simul Healthc 2013;8:335-40. [CrossRef]

17. Seybert AL, Barton CM. Simulation-based learning to teach blood pressure assessment to doctor of pharmacy students. Am J Pharm Educ 2007;71. [CrossRef]

18. Sarmasoğlu Ş, Dinç L, Elçin M. Using standardized patients in nursing education effects on students' psychomotor skill development. Nurse Educ 2016;41:E1-5. [CrossRef]

19. Jeffries PR, editor. Simulation in Nursing Education From Conceptualization to Evaluation, 2nd ed. New York: National Leaguge for Nursing; 2012. pp.1-25.

20. Oermann MH, Gaberson KB. Evaluation and Testing in Nursing Education, 4th ed. New York: Springer Publishing Company; 2014. p.40.

21. Turgut MF, Baykul Y. Eğitimde Ölçme Değerlendirme, 4. Baskı. Ankara: Pegem Akademi; 2012. ss.122-31.

22. Şahin TK, Demir LS, Koruk İ. Bir tıp fakültesi hastanesinde görevli hemşirelerin kan basıncı ölçüm bilgilerinin değerlendirilmesi. TSK Koruyucu Hekimlik Bülteni 2006;5:8-18. Erişim: https://www. scopemed.org/mnsfulltext/khb_005_01-8.pdf?t=1566477183

23. Eghbalibabadi M, Ashouri E. Comparison of the effects of two teaching methods on the nursing students' performance in measurement of blood pressure. Iran J Nurs Midwifery Res 2014;19:381-4.

24. Gazibara T, Rancic B, Maric G, Radovanovic S, Kisic-Tepavcevic D, Pekmezovic T. Medical students, do you know how to measure blood pressure correctly? Blood Press Monit 2015;20:27-31. [CrossRef]

25. Zaybak A, Yapucu Güneş Ü. Hemşirelerin indirekt arteriyel kan basıncı ölçüme yöntemleriyle ilgili gözlemsel bir çalışma. CÜ Hem YO Derg 2007;11:23-8. Erişim: http://eskidergi.cumhuriyet.edu.tr/ makale/1621.pdf

26. Lynn P, editor. Taylor's Clinical Nursing Skills, 3rd ed. Philadelpia: Lippincott Williams \& Wilkins; 2011. pp.33-43. Erișim: http://www. zu.edu.jo/UploadFile/Library/E_Books/Files/LibraryFile_16105_10. pdf

27. DeLaune SC, Ladner PK. Fundamentals of Nursing Standard \& Practice, 4th ed. Delmar: Cengage Learning; 2011. pp.533-7.

28. Atabek Aştı T, Karadağ A, editörler. Hemşirelik Esasları. İstanbul: Akademi Yayınevi; 2013. ss.611-9.

29. Handler J. The importance of accurate blood pressure measurement. Perm J 2009;13:51-4. [CrossRef]

30. Pinar R, Ataalkın S. The effect of clothes on sphygmomanometrıc blood pressure measurement in hypertensive patients. Eur J Intern Med 2009;20:S277-78. [CrossRef] 